Teologia i Moralność, Volumen 15(2020), numer 2(28)

doi: 10.14746/tim.2020.28.2.08

ORCID: 0000-0003-4468-9279

\author{
WOJCIECH SURMIAK \\ Uniwersytet Śląski w Katowicach \\ Wydział Teologiczny
}

\title{
Zdrowie publiczne - przemyśleć bioetykę na nowo. Od zasady autonomii do zasady odpowiedzialności
}

Bioetyka jest dyscypliną filozoficzną i teologiczną, która powstała w latach siedemdziesiątych XX wieku. Próbuje się ona zmierzyć z problemami etyczno-moralnymi na forum praktyki klinicznej oraz na polu badań naukowych w zakresie szeroko rozumianej medycyny czy też troski o życie i zdrowie człowieka ${ }^{1}$. Z tej też racji bioetyka charakteryzuje się zawsze silnie etycznym ukierunkowaniem podejścia do problemów życia i zdrowia poszczególnych jednostek oraz do troski o zdrowie podejmowanej przez pracowników służby zdrowia zarówno w wymiarze realizowanej przez nich praktyki klinicznej, jak i wspomnianych już badań naukowych. To osobiste zaangażowanie pacjenta i lekarza jest jedną z racji, dla których od samego początku namysłu bioetycznego przywoływano zasady, które mają najbardziej podstawowe znaczenie, a mianowicie autonomii pacjenta oraz konieczności wyrażenia zgody na podjęcie konkretnego zabiegu czy badania.

W ostatnich latach jednak pojawia się coraz mocniej pewien nowy paradygmat uprawiania refleksji bioetycznej w duchu zasady odpowiedzialności, szczególnie na forum troski o zdrowie publiczne, która to w przeciwieństwie do medycyny leczniczej swoje działania skupia nie na pojedynczych osobach, ale na całej społeczności (Wojtczak 2009, 1). Bez wątpienia ta nowa refleksja wzbogaca i dopełnia wciąż jeszcze krótką akademicką historię uprawiania bioetyki. W niniejszym artykule zostaną ukazane pewne elementy etosu lekarskiego i etyki badań naukowych na płaszczyźnie medycznej, które muszą

${ }^{1} \mathrm{~W}$ niniejszym tekście troska o życie i zdrowie zostanie ograniczona do tzw. wąskiego ujęcia przedmiotu bioetyki, czyli do życia i zdrowia człowieka. Istnieje bowiem także szerokie ujęcie przedmiotu bioetyki traktujące o życiu i zdrowiu w ogóle (tzw. bioetyka globalna). 
zostać ujęte w przestrzeni tzw. medycyny zapobiegawczej, gdyż bez takiego podejścia byłoby niezmiernie trudne podejmowanie słusznych działań na płaszczyźnie zdrowia publicznego, którego celem jest ,utrzymanie i poprawa stanu zdrowotności oraz zapobieganie zachorowaniom i przedwczesnym zgonom z aktywnym uczestnictwem ludzi i wsparciem administracji państwa" (Wojtczak 2009, 1).

Warto już na wstępie zauważyć, że etyka zdrowia publicznego jest pewną koncepcją podejmowaną $\mathrm{w}$ duchu odpowiedzialności, która powinna zdobyć bardziej znaczącą pozycję w stosunku do ugruntowanej już w bioetyce zasady autonomii. Odwołując się do zasady odpowiedzialności, przyjmuje się założenie, że człowiek jako istota rozumna, a jednocześnie wyposażona w zdolność odróżniania dobra i zła, kieruje się przede wszystkim własną wolą. Realizuje w ten sposób swą wolność jednostkową, czyli osobową. Podstawowym założeniem doświadczenia przeżywania swej wolności przez człowieka jest ponoszenie konsekwencji własnych zachowań. Samo pojęcie odpowiedzialności nieprzypadkowo ma takie same korzenie co „odpowiedź”. Odpowiedzialność za coś/kogoś zakłada bowiem, ,że powinnyśmy zdać sobie sprawę z własnych zachowań, wytłumaczyć je, usprawiedliwić, zareagować na pytanie o przyczyny naszego postępowania itp." (Chauvin, Stawecki, Winczorek 2019, 280).

Jednocześnie warto podkreślić różnicę pomiędzy odpowiedzialnością retrospektywną (odpowiedzialnością za to, co już się wydarzyło) a odpowiedzialnością perspektywiczną (odpowiedzialnością, która wybiega w przyszłość). Wydaje się bowiem, że jedynie takie odpowiedzialne perspektywiczne spojrzenie jest cechą, która daje możliwość tworzenia właściwej etyki zdrowia publicznego. Jednocześnie trzeba nadmienić, że zarysowujący się niejako konflikt pomiędzy autonomią i odpowiedzialnością jest jedynie pozorny, gdyż każda odpowiedzialność zawiera w sobie niezbędny element respektu dla autonomii pacjenta. Taki punkt widzenia wydaje się użyteczny także dla samej bioetyki, w której to właściwe odwołanie się do odpowiedzialności pozwala przezwyciężyć nienowy już konflikt pomiędzy dobroczynnością a autonomią. Konflikt ten był jednym z głównych problemów bioetyki od początku jej istnienia. Odpowiedzialność ukazuje bowiem właściwą równowagę pomiędzy dobroczynnym działaniem a autonomią pacjenta. Wyrażają to dwa znaczenia oblicza odpowiedzialności: odpowiedzieć komuś (odpowiadać przed kimś) i odpowiedzieć na coś (odpowiadać za coś). Tak rozumiana idea odpowiedzialności stała się częścią składową refleksji na temat stosunku człowieka do drugiego człowieka (refleksji etycznej, moralnej), stosunku człowieka do bogów czy Boga (refleksji religijnej), jak również refleksji prawnej. W końcowym fragmencie artykułu zostaną zaproponowane pewne przykłady zastosowania tego modelu etycznego zbudowanego na odpowiedzialności na polu 
problematyki zdrowia publicznego, który daje właściwą równowagę pomiędzy tymi dwoma głównymi znaczeniami odpowiedzialności.

Zaproponowany w niniejszym artykule model etyczny wpisuje się pomiędzy perspektywę wolnościową, dającą priorytet jednostce, która otwiera się na państwo w minimalnym stopniu, a perspektywą kolektywistyczną, który zdaje się promować większe dobro wspólnotowe, a prawa jednostki nie są rozumiane jako własne, ale jedynie jako będące w służbie wspólnej woli całej wspólnoty.

\section{Zdrowie publiczne i ograniczenia autonomii}

Od samego początku dyskursu bioetycznego autonomia była przyjmowana jako wartość podstawowa. Tak mocne podkreślanie zasady autonomii wynikało ze znaczenia, jakie w bioetyce przypisywano problemom, które pojawiały się na linii relacji lekarz-pacjent czy to w kontekście działań klinicznych, czy to ze względu na poszanowanie praw jednostek, uczestniczących w biomedycznych badaniach naukowych (D’Agostino, Palazzani 2007, 34). Jak podkreślają Daniel Callahan i Bruce Jennings „od samego początku bioetyki dobro jednostki, a w szczególności jej autonomia, były tematem dominującym” (Callahan, Jennings 2002, 169).

Na polu praktyki klinicznej bioetyka wprowadziła zasadę respektowania autonomii pacjenta, stawiając ją niejako w przeciwwadze do starożytnej etyki medycznej, która była oparta zasadniczo na principium dobroczynności i paternalistycznej pozycji lekarza. Analogiczny fenomen można potwierdzić na płaszczyźnie medycznych nauk eksperymentalnych. Proces w Norymberdze, a także inne szokujące przypadki zweryfikowane np. w Stanach Zjednoczonych, świadczą o organizowaniu niebezpiecznych dla zdrowia eksperymentów bez wyrażenia uprzedniej zgody uczestników na ich przeprowadzenie (Turoldo 2014, 55-61) i zaoowocowały zdecydowanie większym dowartościowaniem - szczególnie w sektorze badań naukowych - zasady autonomii pacjenta (Kowalski 2009, 50-54). Wiąże się ona z koniecznością dostarczenia pacjentowi rzetelnych informacji na temat planowanych działań oraz wyrażenia zgody na uczestnictwo w eksperymencie. Wspomniani Callahan i Jennings sugerują jednakże, że „,bioetyka otrzymała swój pierwszy bodziec dotyczący możliwych nadużyć w badaniach na osobach ludzkich ze strony rodzącego się ruchu ochrony praw pacjentów i swoistego rozwoju medycyny wysokiej technologii" (Callahan, Jennings 2002, 169).

Bardzo podobny opis początków bioetyki znajduje się u Ronalda Bayera i Amy Fairchild: „Lata sześćdziesiąte i siedemdziesiąte [XX w. - WS] świadczyły o nadzwyczajnych wyzwaniach w stosunku do ogólnego rozumienia autorytetu medycyny. Rzeczą najbardziej zaskakującą był fakt, że dotychcza- 
sowy paternalistyczny autorytet lekarzy został poddany krytyce przez nową etykę medyczną, która przypisywała honorowe miejsce koncepcji autonomii. Od pierwotnego skupiania się na działaniach związanych z praktyką medyczną, podkreślanie autonomii przeszło także do badań naukowych. W ten sposób - w okolicznościach ujawnienia pewnego skandalu i nadużycia - rozwinęła się nowa etyka badań naukowych, która stymulowana była wokół zamętu wywołanego przez ujawnienie faktów pogwałcenia godności osoby ludzkiej, które dokonywały się pod egidą badań medycznych w nazistowskich Niemczech. Formalną bazą tej nowej wizji etycznej było przekonanie, że żadna osoba nie może być zaangażowana w uczestnictwo w planach badawczych - nawet ze względu na ich ogromne znaczenie dla dobra publicznego - bez uprzedniej, osobistej zgody na uczestnictwo w tychże badaniach. W ten oto sposób etyka klinicznych badań naukowych i etyka klinicznej praktyki medycznej połączyły się we wspólnym zadaniu ochrony autonomii i praw jednostki" (Bayer, Fairchild 2004, 473-474).

To ,ukierunkowanie na jednostkę wynikające z zasady autonomii, zdominowało bioetykę od środka" (Callahan, Jennings 2002, 170) pomimo wciąż istniejących pewnych tendencji zachowawczych i krytycznych wobec takiej praktyki, ponieważ ,zgodnie z tendencjami kulturalnymi lat siedemdziesiątych i osiemdziesiątych w celebrowaniu wyboru i wolności jednoczyły one w sobie lewicowo ukierunkowaną politykę i handel ukierunkowany wolnorynkowo" (Callahan, Jennings 2002, 169-170). Współcześnie domaga się zmiany kierunku na polu bioetyki, ponieważ rozszerzanie się tej dyscypliny na problemy z zakresu zdrowia publicznego, które związane są z zagadnieniami zdrowia całej populacji i społeczeństwa, czyni koniecznym ponowne przemyślenie czysto indywidualistycznego ukierunkowania bioetyki. W rzeczywistości bowiem zdrowie publiczne dotyka wielu aspektów medycyny klinicznej, ale też znacząco różni się w podejściu do pacjenta. Na pierwszym miejscu różnica ta objawia się w aktywności bazowej, gdyż medycyna kliniczna daleko bardziej zainteresowana jest leczeniem pacjenta, podczas gdy głównym polem zainteresowania zdrowia publicznego jest działalność prewencyjna. Następna różnica objawia się w samym sposobie podejścia do pacjenta, gdyż medycyna kliniczna podejmuje troskę o poszczególne osoby, podczas gdy zdrowie publiczne zajmuje się stanem zdrowia całej populacji. I w końcu, używając znaczących terminów, w rzeczywistości „w bioetyce znajdujemy przeważające ukierunkowanie na korzyść wolności obywateli i osobistej autonomii, w przeciwieństwie do ukierunkowania utylitarystycznego, paternalistycznego i wspólnotowego, które charakteryzują zakres tematyczny problematyki zdrowia publicznego poprzez całą historię" (Callahan, Jennings 2002, 170).

Jeśli należałoby w rygorystyczny sposób aplikować principium autonomii na polu zdrowia publicznego, tak jak została ta zasada zastosowana na 
forum badań biomedycznych lub w praktyce klinicznej, to nie byłby możliwy jakiekolwiek rodzaj interwencji na forum zdrowia publicznego (Wróbel 1999, 119-125). W rzeczywistości bowiem interwencje w zakresie zdrowia publicznego ograniczają autonomię pacjenta daleko bardziej niż w praktyce klinicznej, gdyż chodzi tutaj o ingerencje określone w sposób prawny i mające charakter obowiązkowy. W rzeczywistości jednak - jak podkreślają niektórzy - „działania w zakresie zdrowia publicznego mogą być przymusowe, co więcej wzmocnione nawet poprzez siły policyjne i interwencje, które są nakładane bez zachowania konkretnych procedur powiązanych z koniecznością uzyskania zgody ze strony człowieka, czyli bez zachowania procedur, które są w normalny sposób niezbędne w praktyce klinicznej” (Rogers, Brock 2004, 3; por. Gostin 2000).

Fundamentalne zasady moralne zdrowia publicznego zostały w jasny sposób wyrażone przez lekarza Hermanna Biggsa (1859-1923), jednego z najbardziej wpływowych urzędników służb sanitarnych USA. Jest on autorem serii nowych procedur na forum zdrowia publicznego w XIX i XX wieku. Napisał między innymi, że „rząd Stanów Zjednoczonych Ameryki jest demokratyczny, ale stosowane przez niego zasady sanitarne są często autokratyczne, a działania podejmowane przez władze sanitarne są działaniami o charakterze paternalistycznym. Jesteśmy zmuszeni, kiedy to jest tylko konieczne do ich wprowadzenia i respektowania, a ludzie są gotowi do ich zaakceptowania nawet wedle miary, która mogłaby wydawać się nader radykalna i arbitralna, o ile tylko zostałaby ona w jasny sposób zaprojektowana dla dobra publicznego i jako przynosząca ewidentne i efektywne dobro dla całej wspólnoty" (Biggs 1987, 28).

Z kolei Nancy Kass napisała, że kodeksy „etyczne medycyny i etyczności badań naukowych, generalnie dają maksymalne pierwszeństwo indywidualnej autonomii pacjenta, pierwszeństwo, które nie zawsze może być pojmowane adekwatnie przez działania z zakresu praktyki zdrowia publicznego" (Kass 2001, 1776). W ten sam sposób, kiedy działania z zakresu zdrowia publicznego nie mają dla obywateli charakteru przymusowego, ale jedynie cel informacyjny co do skutków chorobowych niektórych stylów życia (np. palenia tytoniu, nadużywania alkoholu lub niewłaściwego odżywiania się), to założony cel prewencyjny nie może być osiągnięty poprzez zachowanie tradycyjnych reguł rzetelnego poinformowania pacjenta i konieczności wyrażenia przez niego zgody na podejmowane działania. Nurit Guttman i Charles Salmon zaznaczają w tym kontekście, że ,przez wieki rządzący i instytucje społeczne podejmowały różnego rodzaju strategie komunikacyjne w służbie zdrowia publicznego, używając taktyk, które niektórzy mogą pojmować jako «zamierzona manipulacja publiczna». Instytucje te mają w rzeczywistości często jako swój przedmiot niejako «sprzedaż» pewnych praktyk promujących zdrowie, 
takich jak np. praktyki przeciwdziałające wysokiemu ciśnieniu krwi czy rakowi piersi lub też powstrzymywanie się od palenia tytoniu lub nadużywania spożycia pokarmów bogatych w nasycone kwasy thuszczowe" (Guttman, Salmon 2004, 532-533). I dalej: „w świecie przesyconym wiadomościami medialnymi pracownicy służby zdrowia publicznego muszą wręcz współzawodniczyć w możliwości zdobycia społecznej uwagi: co może spowodować zastosowanie «szokujących taktyk» lub bardzo silnych wezwań o charakterze emocjonalnym. Ostatnio chęć zdobycia publicznej uwagi objawia się w korzystaniu z danych statystycznych obrazujących istniejące ryzyko" (Guttman, Salmon 2004, 539).

Inna technika, o wątpliwej użyteczności według opinii niektórych osób, opiera się na świadomym przesadzaniu w ujawnianiu czynników negatywnych diagnozujących problem, w sposobie ich prezentacji przez władzę lub w ukazywaniu jednostronnych argumentów albo ich świadomej selekcji. Dla przykładu można pomyśleć o typowym ogłoszeniu, którego treść można znaleźć na opakowaniu papierosów: „Palenie zabija”. W tego typu ogłoszeniach relacja pomiędzy paleniem a śmiercią palacza jest przedstawiona w sposób bezwzględny, podczas gdy każdy zdaje sobie sprawę, że rzeczywistość jest bardziej złożona. W rzeczywistości ogłoszenie powinno mówić o tym, że zgodnie z danymi statystycznymi wśród osób palących papierosy oraz mających pewne predyspozycje genetyczne istnieje znaczne prawdopodobieństwo rozwoju raka płuc lub innych chorób, które mogą prowadzić do śmierci. Oczywiście są wśród palaczy przypadki (i to nierzadkie zresztą), u których nie rozwija się ani rak płuc, ani żadna inna choroba wiązana tradycyjnie z paleniem tytoniu. Jest oczywiste, że gdyby taki treściowy zapis ogłoszenia został umieszczony na opakowaniu papierosów, skutek nie byłby taki sam, jak w przypadku informacji: „Palenie zabija”, nikt nie protestuje przeciwko tak mocnemu przekazowi, gdyż chce on podkreślić potencjalną szkodę. Przekaz ten jest czyniony także w dobrej intencji (Turoldo 2011, 78-79). Zresztą do podejmowania akcji edukacyjnych, które mają na celu profilaktykę i odwodzenie od palenia, wzywa sama Nowa Karta Pracowników Stużby Zdrowia (Papieska Rada ds. Duszpasterstwa Służby Zdrowia, nr 127).

\section{Zasada odpowiedzialności}

Jeśli zatem sama zasada autonomii wydaje się niewystarczająca $\mathrm{i}$ - być może - nawet niejednokrotnie problematyczna w zakresie etyki zdrowia publicznego, to jakie zatem może być fundamentalne principium operatywne dla tego szczególnego działu medycyny? Właściwie można by odpowiedzieć na tak postawione pytanie, jednym słowem: odpowiedzialność albo jeszcze 
bardziej precyzyjnie - szczególny rodzaj odpowiedzialności, który różni się od odpowiedzialności nałożonej jedynie przez prawo cywilne czy karne. Na forum prawa bowiem odpowiedzialność jest pewną umową, w której przypisujemy działającemu określone konsekwencje wynikające z podjętego przez niego działania. W prawie cywilnym odpowiedzialność rozumiana jest jako przypisywanie osobie skutków jej działania lub zaniechania i zawiera w sobie obowiązek kompensacji szkód spowodowanych z własnej winy, tak jak to zostało przewidziane $\mathrm{w}$ prawie. W prawie karnym zaś odpowiedzialność zawiera w sobie obowiązek poddania się przewidzianej w kodeksie karze. Zasada przypisywania skutków czynu jest szczególnym rodzajem odpowiedzialności, który można zdefiniować jako pewną „odpowiedzialność następczą”, wynikającą z faktu, że następuje ona (a nie poprzedza) jako efekt działania, a samo działanie niejednokrotnie już dokonane może być przypisane swojemu sprawcy, który jest za nie odpowiedzialny.

Zastosowanie zasady odpowiedzialności na forum zdrowia publicznego należy jednak widzieć w zupełnie innym znaczeniu. W rzeczywistości bowiem nie polega ona jedynie na odpowiedzialności za to, co się już wydarzyło. Jest natomiast odpowiedzialnością za to, co może się wydarzyć, o ile nie zostaną zastosowane wszystkie możliwe i dostępne środki prewencyjne. W sektorze zdrowia publicznego odpowiedzialność jest umową, nie tylko w rozumieniu odpowiedzialności następczej (tak jak w prawie cywilnym lub karnym), ale także (a może przede wszystkim) jako odpowiedzialność uprzednia. Ten typ odpowiedzialności jest związany $\mathrm{z}$ istnieniem pewnych uwarunkowań lub stanu faktycznego, tak jak mówi się, że rodzice są odpowiedzialni za szkody wyrządzone przez ich dzieci. Podczas gdy odpowiedzialność następcza jest silnie związana z karą (Chauvin, Stawecki, Winczorek 2019, 284), odpowiedzialność uprzednia jest w bezpośredni sposób wolna od takich powiązań. W przypadku odpowiedzialności następczej cała uwaga jest skoncentrowana właściwie na osobie winnej, czyli osobie, której zostało przypisane złe działanie i jego skutki, podczas gdy w odpowiedzialności następczej jest przeciwnie, uwaga skupia się w niej na potencjalnych ofiarach, mimo iż w danej chwili nie podjęto jeszcze żadnych złych działań, a możliwość zaistnienia szkody jest jedynie potencjalna i nie do końca zweryfikowana. W ten oto sposób odniesienia do kary i winy (jak w przypadku odpowiedzialności następczej) mogą być wyłączone z koncepcji odpowiedzialności uprzedniej i zastąpione przez idee: solidarności, bezpieczeństwa i grożącego ryzyka. W ten sposób uwaga przenosi się z rzekomego sprawcy szkody, która powinna być kompensowana także w przypadku braku złego zachowania, na potencjalną jej ofiarę. Obiektywna ocena zagrażającej szkody dąży do zniesienia subiektywnego związku pomiędzy działaniem a jego wykonawcą na korzyść rachunku prawdopodobieństwa, który kształtuje analogiczne sytuacje. Jak wskazał Paul Ricoeur: „W epoce, 
w której wina, ryzyko wypadku i natychmiastowa szkoda są sercem problematyki praw i obowiązków, nie dziwi fakt, że osoby słabe i wrażliwe pojmuje się jako moralnie równe z przedmiotami odpowiedzialności" (Ricoeur 1995, 62-65).

\section{Odpowiedzialność zawiera w sobie respektowanie autonomii}

Odpowiedzialność, jak sugeruje etymologia słowa, jest odpowiedzią. Odpowiedź ta może przybierać różne formy. Na jednym poziomie jest odpowiedzią udzieloną komuś, kiedy o coś prosi (na przykład, gdy ktoś prosi o przerwanie leczenia). W tym znaczeniu udzielona w duchu odpowiedzialności odpowiedź wyraża uznanie dla autonomii pacjenta. Na drugim poziomie odpowiedzialność oznacza „odpowiedzieć” przez działania, które mają wpływ wobec wyzwań przyszłości. W praktyce klinicznej to znaczenie odpowiedzialności może być równoznaczne z pewnym rodzajem zasady dobroczynności (primum non nocere), podczas gdy w etyce środowiskowej charakteryzuje się braniem pod uwagę przyszłych pokoleń.

Koncepcja odpowiedzialności jest tak bogata i wielowarstwowa, że może wydawać się wręcz paradoksalna. W przypadku zdrowia publicznego bycie odpowiedzialnym za populację narażoną na działanie niebezpiecznego wirusa wymaga wdrożenia koniecznych procedur i działań. Niejednokrotnie musi się to odbywać kosztem niecałkowitego zachowania zasady o konieczności wyrażenia osobistej zgody przez pacjenta. Wyrażenie zgody wiązałoby się z obowiązkiem: udzielenia każdemu pacjentowi należytych informacji, odpowiedzi na wszystkie prośby o wyjaśnienia wszelkich wątpliwości związanych z procedurami poprzez udzielanie obszernych i wszechstronnych informacji oraz kierowania indywidualnych próśb o udzielenie zgody na planowane działania przed ich rozpoczęciem. Należałoby zatem przebyć bardzo długą drogę proceduralną, zanim zostałyby uruchomione konkretne procedury.

Jaka zatem zasada powinna rozwiązywać istniejące w tej sytuacji konflikty? Wydaje się, że trudno o sformułowanie pewnej ogólnej reguły, a konflikty muszą być rozwiązywane z uwzględnieniem konkretnego przypadku i kontekstu, w którym się rozgrywają. Trudno jest bowiem odpowiedzieć na pytanie przed wystąpieniem danego faktu: Czy lepszym działaniem jest przymusowa ewakuacja ludności, która mogłaby doświadczyć działania toksycznej chmury lub epidemii, czy też lepszym jest docieranie do każdej poszczególnej osoby z konkretnymi wyjaśnieniami, które pomogą w podjęciu autonomicznej decyzji? Drugi przypadek zawiera w sobie poważne ryzyko śmierci ludności w trakcie zbierania wymaganych przez zasadę autonomii zgód na przeprowadzenie procedur medycznych czy ewakuacyjnych. 
Wybór jest jednak w rzeczywistości zależny od rodzaju interwencji i od zakresu, w jaki wpływa ona na ewentualne złamanie podstawowych praw jednostki. Wybór ten zależy także od celowości działań, ryzyka, które niosą, oraz od sposobu, w jaki ograniczają wolność osobistą. Syntetyzując dotychczasowe wskazania, należy podkreślić, że właściwa ocena stosowanych procedur i działań zależy od poprawnej i aktualnej oceny istniejących okoliczności, które determinują daną sytuację. Zdolność do adekwatnej oceny wszystkich aktualnych okoliczności obecnych w zaistniałej sytuacji tworzy jedną z fundamentalnych cech charakteryzujących odpowiedzialność. Wyraża to także sam termin w języku łacińskim: res (rem) ponderare, czyli 'zważyć', 'odzwierciedlić', 'należycie ocenić pewną rzecz/sytuację'.

Ten szczególny rys znaczenia odpowiedzialności jest bardzo mocno podkreślony przez naukowców skupionych wokół Jamesa Childressa. Piszą oni: „Od momentu, od którego każde działanie szczegółowe na forum zdrowia publicznego - czy to w znaczeniu praktycznym, czy politycznym - może mieć także pewne cechy, które naruszają czy to jedną, czy nawet więcej wskazań moralnych natury ogólnej, staje się koniecznym określenie, które z tych działań mają charakter priorytetowy. Niektóre z nich przynoszą racjonalne argumenty za hierarchią leksykalną lub seryjną, według której jedna zasada - nie będąc zasadą absolutną - determinuje wskazówki moralne drugiej, co może skutkować priorytetowym respektowaniem tej drugiej. Na przykład w teorii można by utrzymywać, że wolność jednostki ma zawsze pierwszeństwo w obliczu ochrony i promocji zdrowia publicznego. Żadna z tych reguł pierwszeństwa jest nie do przyjęcia, co więcej jakakolwiek norma pierwszeństwa, która wydawałaby się do przyjęcia, powinna być prawdopodobnie implikowana jedynie jako pewne szczególne ograniczenia i restrykcje w celu redukcji konfliktów wobec istniejącej hierarchii pryncypiów moralnych. $\mathrm{Z}$ naszego punktu widzenia zaś, jest lepszym rozeznanie konieczności podejmowania konkretnego działania w sytuacji konfliktowej, pośród różnych wskazówek moralnych natury ogólnej, oceniając uważnie zaistniałe okoliczności. Jesteśmy w stanie określić z wyprzedzeniem ciężar różnych argumentacji moralnych, a możemy to uczynić jedynie poprzez branie pod uwagę szczególnego kontekstu, który może wpływać na ich ciężar" (Childress, Faden, Gaare 2002, 172).

Zatem także odpowiedzialność jest częścią tej samej rodziny cnót, do której należy phronesis (o której pisze Arystoteles), ponadto wpisuje się w naukę o sądzie moralnym w określonej sytuacji i okolicznościach (bliską Hansowi Georgowi Gadamerowi) i w naukę o sądzie reflektującym (która znajduje swoje odzwierciedlenie w Krytyce władzy sadzenia Immanuela Kanta). Działanie podejmowane w sposób odpowiedzialny jest w rzeczywistości analogiczne do działania podejmowanego w sposób mądry. Nie utożsamia się ono ani z mechaniczną aplikacją abstrakcyjnych reguł, ani z postępowaniem ,po omacku”, 
a zatem bez jakiegokolwiek prowadzenia przez zasady uniwersalne. Człowiek podejmujący odpowiedzialne działanie zna reguły etyczne i aplikuje je w całej rozciągłości ludzkiego doświadczenia, używając przy tym właściwego rozeznania i przechodząc drogę od własnych zwyczajów do prawdziwie dobrego działania (Turoldo 2011, 82).

\section{Rodzaje interwencji na płaszczyźnie zdrowia publicznego}

W jaki sposób zatem powinny interweniować służby odpowiedzialne za zdrowie publiczne? Jakie są efektywne sposoby działania służb realizowane w różnych krajach? Wyróżnia się trzy rodzaje interwencji: nieprzymusowe, nieznacznie przymusowe, silnie przymusowe.

\subsection{Interwencje nieprzymusowe}

Interwencje nieprzymusowe są działaniami, które ograniczają się do monitorowania istniejącej sytuacji, poprzez udzielanie użytecznych informacji osobom, które chcą zmienić swój sposób zachowania określanego jako ryzykowne, oferując im wsparcie psychologiczne i materialne lub poprzez wybory, które prowadzą do ustandaryzowanych procedur.

Najbardziej akceptowalne dla opinii publicznej wydają się te interwencje, które pomagają osobom w podjęciu decyzji, co jest poprzedzone rzetelną informacją. Chodzi tutaj przede wszystkim o ograniczenie możliwości złych decyzji. Interwencje te są jednymi z typowych działań właściwych w przeciwdziałaniu palenia tytoniu. O negatywnych skutkach nikotynizmu informuje kupującego stosowny zapis umieszczony na paczce papierosów.

Taka polityka może być także z sukcesem zastosowana na płaszczyźnie promocji określonej diety lub sposobów odżywiania. Niektórzy dietetycy wskazują na to, że wiedza z zakresu wartości odżywczej pokarmów ma znaczący wpływ na wybory żywieniowe. Dowodzi tego na przykład eksperyment przeprowadzony w niektórych stołówkach zakładowych. Przy dwóch różnych okazjach, kiedy były obecne na posiłku te same osoby i w ofercie menu były zaproponowane te same możliwości wyboru dań. W drugim przypadku zostały podane obok potraw informacje co do ich wartości odżywczej, takie jak na przykład: zawartość tłuszczu czy ilość kalorii. W rezultacie eksperymentu nastąpiła istotna zmiana w podejmowanych wyborach. Dania, które były częściej wybierane za pierwszym razem, były pomijane za drugim razem. Dania, które za pierwszym razem były pomijane, były wybierane częściej, kiedy znajdowała się obok nich informacja o ich rzeczywistej wartości odżywczej. 
Ten sposób interwencji jest jednym z bardziej właściwych, który można naśladować jako kryterium prawdziwej odpowiedzialności, ponieważ w tym przypadku brane są pod uwagę dwa wspomniane uprzednio wymiary odpowiedzialności: „odpowiedź dana komuś” (co jest respektem dla autonomii) i „odpowiedzi za" (która jest wzięciem odpowiedzialności za przyszłość drugiego i społeczeństwa). W przedstawionym przykładzie eksperymentu przeprowadzonego w stołówce można dopatrzyć się jeszcze jednego elementu. Wybory osób w pierwszym przypadku nie były decyzjami w pełni autonomicznymi, gdyż osoby te nie do końca uświadamiały sobie to, co rzeczywiście wybierały jako swoje pożywienie. Poprzez decyzję o zamieszczeniu obok pokarmu informacji o jego wartości energetycznej nie tylko wpływa się na wzmocnienie odpowiedzialności za utrwalanie się pewnych zwyczajów wśród ludzi („być odpowiedzialnym za"), ale wzmacnia się także ich autonomię w dokonaniu wyboru (,być odpowiedzialnym wobec”).

Odnalezienie i zachowanie równowagi pomiędzy dwoma obliczami odpowiedzialności jest w omawianym przypadku dosyć łatwe. Nieco inna strategia działań podejmowanych jako interwencje nieprzymusowe zawiera w sobie nakaz, aby producenci substancji trujących brali odpowiedzialność za negatywne skutki stosowania ich produktów w populacji. Ta strategia była stosowana także wobec przedstawicieli przemysłu tytoniowego, i tak w Stanach Zjednoczonych istnieją stowarzyszenia byłych palaczy, którzy zachorowali z powodu palenia tytoniu i którzy sądownie domagają się odszkodowań od producentów tytoniu. Takie procesy sądowe zmusiły producentów papierosów nie tylko do wypłacenia wysokich odszkodowań finansowych, ale i wymusiły to, aby w adekwatny sposób informować swoich klientów o chorobotwórczych efektach palenia papierosów. Ten model mógłby być aplikowany także w sektorze produkcji pożywienia, nade wszystko produktów przeznaczonych dla dzieci w wieku szkolnym. W tym przypadku stara koncepcja prawna odpowiedzialności jako przypisywalności sprawcy skutku ze względu na ich związek przyczynowo-skutkowy może być zastosowana w celu zobligowania producentów do wzięcia odpowiedzialności za ich klientów, w duchu szeroko rozumianej odpowiedzialności społecznej. Zachodzi w tym miejscu ciekawy przypadek tzw. odpowiedzialności ante factum (uprzedniej) stymulowanej przez odpowiedzialność post factum (następczą). W tym przypadku dwie strony odpowiedzialności opisane uprzednio (,bycie odpowiedzialnym za” i „bycia odpowiedzialnym przed”) nie wchodzą w konflikt, ponieważ producenci substancji szkodliwych są zobligowani do „bycia odpowiedzialnymi za” poprzez zobowiązania, które zostały im nakazane, aby informować ludność o szkodliwości produkowanych przez nich środków.

Wskazane zatem typy interwencji nie mają charakteru przymusowego, gdyż dotyczą one jedynie efektów, które dane działania wywołują w popula- 
cji. Kupujący papierosy zostali jedynie poinformowani o skutkach palenia tytoniu, ale w żaden sposób nie zostali zobligowani do niepalenia. Działania te mają pewien charakter przymusowy, ale jedynie w stosunku do producentów wyrobów tytoniowych, lecz nie wpływa to na ostateczną klasyfikację interwencji jako nieprzymusowej, gdyż obligatoryjność działań w zakresie zdrowia publicznego odnosi się w tym przypadku jedynie do populacji.

\subsection{Interwencje nieznacznie przymusowe}

Interwencje o nieznacznym charakterze przymusowym to te, które prowadzą do podejmowania wyborów poprzez ogłoszenia publiczne, formułowane jako zachęty lub jako czynniki zniechęcające oraz takie, które w znaczący sposób ograniczają osobom potencjalne wybory z wyraźnym celem ich ochrony przed możliwymi zagrożeniami. Tego typu działania można zobrazować na trzech przykładach.

Po pierwsze, chodzi tutaj o wszelkiego rodzaju interwencje o charakterze prawnym, które są ukierunkowane na promocję takich stylów życia lub produktów, które są zdecydowanie bardziej zdrowe. Usprawiedliwienie dla tego typu interwencji jest osadzone na przekonaniu, że istniejące w społeczeństwie zwyczaje są nie tyle wynikiem wolnego wyboru, ile rezultatem pewnych uwarunkowań społecznych, które są konsekwencją szerokich akcji reklamowych. Jak wskazują Childress i inni: ,,problemem jest tutaj prześledzenie swoich celów i swoich działań, to znaczy, chodzi o zdiagnozowanie różnego rodzaju wpływów, które oddziałują na osobę podejmującą wybór, które determinują w takim stopniu jej działanie, że nie jest ono już w pełni dobrowolne, chodzi także o określenie negatywnych efektów takich działań podejmowanych przez reklamodawców, które oddziałują na człowieka aż do możliwości kontroli jego życiowych decyzji” (Childress, Faden, Gaare 2002, 176).

Ten typ interwencji wydaje się na pierwszy rzut oka tożsamy z opisanymi uprzednio. Nade wszystko jednak pomiędzy nimi można znaleźć pewne zasadnicze różnice, ponieważ logika reklamy jest niejednokrotnie bardzo odległa od logiki prawdy i rzetelnej informacji. Strategie komunikacyjne, jak już zauważono, zawierają niejednokrotnie pewne manipulacje reklamowe. W świecie przesyconym informacjami medialnymi reklamodawcy muszą między sobą konkurować, aby zdobyć ludzką uwagę. To może wymagać odwołania się do pomocy socjotechniki lub do apelów o silnym zabarwieniu emocjonalnym. Opierają się one na przykład na manipulacji danymi statystycznymi, które pomagają wzmocnić obawy związane z ryzykiem. Oczywiście ta swoista gra danymi statystycznymi polega zarówno na przesadnym ukazywaniu znaczenia niektórych faktorów, jak i ich negatywnych konsekwencji w ocenie wielko- 
ści pewnych problemów lub stopnia kompetencji władz, które formułują dane bądź prezentują w sposób jednostronny argumenty, wybierając spośród nich jedynie te dane, które można odczytać na swoją korzyść.

Po drugie, należy wspomnieć o zastosowaniu pewnych czynników finansowej zachęty lub zniechęcenia, jak na przykład podniesienie podatków na żywność mniej zdrową lub obniżenie podatków w stosunku do zdrowej żywności. Taka polityka zwana fat tax jest zalecana między innymi przez Światową Organizację Zdrowia. Mechanizmy o charakterze finansowym są także często podejmowane przez zniechęcanie np. do palenia tytoniu lub używania napojów alkoholowych, czyli produktów, które są obarczone przez prawie wszystkie państwa wysokimi akcyzami i podatkami. Finansowym czynnikiem zachęcającym są z kolei normy prawne, które przewidują redukcję podatków na zakupy związane np. z aktywnością sportową.

Przymus interwencji wyznaczony jest tutaj poprzez wyższe ceny, które powinny zniechęcać do zakupu pewnych określonych produktów uznawanych za niebezpieczne dla zdrowia. Przymus oparty na finansowych czynnikach zachęcających lub zniechęcających jest przez niektóre osoby traktowany jako coś niesprawiedliwego, ponieważ wysokie ceny niektórych produktów powodują w licznych wypadkach wykluczenie wielu ludzi ubogich z możliwości dostępu do niektórych dóbr. $Z$ całą pewnością nie można jednak powiedzieć, że tego rodzaju interwencje znajdują się w sprzeczności z kryterium odpowiedzialności, ponieważ wyraża się w nich właściwa troska o zdrowie mieszkańców (w znaczeniu odpowiedzialności za) a jednocześnie w takiego rodzaju interwencjach respektuje się także autonomię wyboru poszczególnych jednostek, gdyż pomimo dodatkowych narzutów akcyzowych nakładanych na papierosy czy alkohol, a także wciąż podejmowanych kampanii społecznych związanych z przeciwdziałaniem paleniu papierosów czy nadużywaniu alkoholu, wiele osób wcale nie rzuca palenia czy alkoholu i ciągle wybiera tego rodzaju używki.

Po trzecie, interwencją, która zawiera w sobie przymusową redukcję możliwości wyboru dostępnych dla ludności w związku z jej ochroną, jest chociażby usuwanie niezdrowych składników wchodzących w skład pożywienia czy też usuwanie niezdrowych pokarmów ze sklepów lub restauracji. Aby dać rzeczywisty przykład takiej interwencji, można posłużyć się praktyką stosowaną w wielu państwach, że rząd może prosić placówki oświatowe o wprowadzenie określonych zasad wyżywienia w stołówkach szkolnych lub wprowadzić określone zasady dotyczące kwalifikacji pewnych produktów, które będą dostępne w sklepikach szkolnych czy rozlokowanych na terenie szkoły automatach z napojami i żywnością. Taki typ działania jest w pewien sposób przymusowy, ponieważ wybór uczniów jest ograniczony. Oczywiście uczniowie mają prawo do pełnego wyboru poza szkołą, niemniej to ograniczenie 
na terenie szkoły wydaje się jedynie propozycją pewnego modelu zdrowego odżywiania przynajmniej przez określony czas, w którym to uczniowie przebywają w szkole, bez jakichkolwiek absolutnych nakazów korzystania z tej propozycji.

Wszystkie interwencje opisane w tej sekcji artykułu mogłyby być usprawiedliwione poprzez ich skuteczność (to znaczy poprzez realizację celu, który jest oczekiwany) i proporcjonalność (to znaczy poprzez proporcję ich prawdopodobnych korzyści do stopnia, w jakim ograniczają osobistą wolność). Takie usprawiedliwienie podejmowanych działań wymaga nade wszystko transparentnego przedstawienia ludziom, wyjaśnienia troski o wspólnotę. Gdy nakłada się pewne ograniczenia w duchu odpowiedzialności za wspólnotę, oznacza to „pewną formę nacisku poprzez adekwatne miary przymusu. Wyjaśnienie wspólnotowości zawiera w sobie przyjęcie miar, poprzez które można okazać solidarność z osobami, aby chronić ich interesy i pozyskiwać ich zaufanie" (Childress, Faden, Gaare 2002, 174).

Publiczne usprawiedliwienie podejmowanych działań, jak podkreśla Norman Daniels, wymaga otwartej i publicznej dyskusji, rzetelnej i przejrzystej informacji oraz szczerej motywacji ukazującej racje podejmowania takiej czy innej decyzji (Daniels 2000, 1300-1301). Wymaga to także odwołania się do logicznych argumentów i do różnych form badań i opracowań naukowych, które są uznawane przez bezstronne osoby za ważne i istotne dla danej przestrzeni zdrowia publicznego. Nie sposób pominąc także pewnych procedur odwoławczych i możliwości rewizji decyzji w świetle mogącej się pojawić krytyki ze strony innych zaangażowanych podmiotów. Usprawiedliwienie publiczne „określa bazę zaufania publicznego także wtedy, gdy podjęta polityka narusza lub zdaje się naruszać niektóre wskazówki moralne natury ogólnej” (Childress, Faden, Gaare 2002, 175). Niestety efektywność, proporcjonalność i jasno określone motywacje podejmowanych działań nie są wystarczające dla usprawiedliwienia jeszcze bardziej drastycznych działań przymusowych, jak to zostanie ukazane w dalszej części artykułu.

\subsection{Interwencje silnie przymusowe}

Interwencje o charakterze silnie przymusowym to działania, które eliminują jakikolwiek wybór ze strony pacjentów lub osób mających kontakt z chorymi. W dobie pandemii COVID-19 na nowo przypomniane zostały społeczeństwu, i to w zakresie globalnym, takie słowa jak: dystans, izolacja czy kwarantanna. Do grupy interwencji stricte przymusowych zalicza się najstarsze znane formy interwencji na polu zdrowia publicznego. Rozpiętość działań w tym zakresie mieści się pomiędzy obowiązkiem poddania się kontroli lub obserwa- 
cji w zakresie całej populacji lub też pomniejszych grup, które są szczególnie narażone na różnego rodzaju infekcje lub epidemie wirusowe, a prawdziwą i właściwą izolacją przymusową i kwarantanną kontrolowaną przez nadzór służb państwowych. Jak widać, działania te zawierają w sobie podwyższony stopień przymusu i ograniczenia wolności osobistej. Są one jednak konieczne w celu: ochrony jednych osób przed możliwością zakażenia przez inne osoby i powstrzymania dalszego rozprzestrzeniania się epidemii choroby zakaźnej, czyli choroby wywołanej przez biologiczne czynniki chorobotwórcze. Problemem w tym względzie jest jednak zawsze należyta umiejętność rzetelnej oceny: niebezpieczeństwa związanego z daną chorobą zakaźną, skali jej transmisji i związanego z nią zagrożenia dla życia osób (Bzdęga 2010, 369).

W demokratycznych społeczeństwach wprowadzenie interwencji przymusowych powinno być etycznie usprawiedliwione, kiedy nakładają ograniczenia na indywidualne zachowania, które mają negatywny wpływ na inne osoby. Z tej racji nawet sam John Stuart Mill, który był wielkim propagatorem wolności osobistej i utylitaryzmu, zgadza się z ograniczeniem szkodliwych działań, które dotykają innych, o ile takie działania, mówiąc językiem Stuarta Milla, wpływają na innych „,bez ich świadomej i dobrowolnej zgody oraz ich udziału" (Stuart Mill 1976, 71; Mepham 2008, 34).

Główny problem związany z monitorowaniem osób dotkniętych chorobami zakaźnymi, nadzorem nad nimi i koniecznością ich izolacji dotyczy możliwego dalszego rozprzestrzeniania się patogenów (Jędrychowski 2010, 51) ${ }^{2}$. Łatwiej zrozumieć i usprawiedliwić działania bezwzględnie przymusowe w sytuacji szczególnych interwencji w czasie pandemii, tak jak w przypadku ostrego zespołu niewydolności oddechowej (SARS), ptasiej grypy czy ostatnio COVID-19. Trochę trudniej o to zrozumienie w przypadku zakażeń chorobami, które mogłyby wymagać ujawnienia pewnych danych wrażliwych. Tak mogłoby być w przypadku zakażenia HIV i osób chorych na AIDS. Używając dalej przykładu zakażenia się wirusem HIV, należy podkreślić, że identyfikacja choroby, monitoring i ochrona osób wymagałaby, aby rozszerzyć je nie tylko na perinatologię i neonatologię (wertykalna droga zakażenia), ale i grupy podwyższonego ryzyka w zachorowalności, takie jak osoby: korzystające ze środków narkotykowych przyjmowanych drogą pozajelitową (parenteralna droga zakażenia), praktykujące zachowania homoseksualne lub decydujące się na permisywne zachowania seksualne (seksualna droga zakażenia) (Pacian 2014, 156-157).

\footnotetext{
${ }^{2}$ W Polsce choroby zakaźne podlegają obowiązkowemu zgłoszeniu od 1919 roku. Istnieje obowiązek zgłaszania 45 chorób zakaźnych, spośród których 21 podlega przymusowej hospitalizacji, osiem natomiast przymusowemu leczeniu w zakładach otwartej opieki zdrowotnej.
} 
Można by zatem powiedzieć, że niektóre ograniczenia przymusowe wchodzą w zakres, który jest określany i pojmowany jako indywidualna prywatność osoby, jej autonomia i wolność. Nade wszystko jednak, kiedy zostaje osiągnięty poziom niekoniecznych dyskryminacji lub przesadnych ingerencji w życie prywatne, nie może być on usprawiedliwiany poprzez principium odpowiedzialności i wolę zgłębiania w nich wszystkich problemów moralnych. Przyjęta polityka zdrowia publicznego powinna respektować dwa oblicza zasady odpowiedzialności i szukać drogi maksymalnego zredukowania możliwości jakiegokolwiek pogwałcenia zasady autonomii: „Fakt, że określona polityka może łamać ogólne principium moralne, stawia postulat szukania strategii alternatywnych, które są moralnie mniej angażujące. Taka jest logika pewnych ogólnych wskazań moralnych lub tzw. prima facie. Na przykład, biorąc pod uwagę pewne okoliczności, polityka ochrony zdrowia, która przewiduje pewne zachęty dla osób chorych na grú́licę, aby dobrowolnie poddały się pełnemu leczeniu aż do pełnego wyzdrowienia, ma pierwszeństwo przed polityką, która w przymusowy sposób nakazuje takie leczenie aż do jego zakończenia. Innymi słowy: są i zwolennicy takiej drugiej strategii, którzy znają ciężar zawartej w niej próby moralnej. To oznacza, że każdy, kto proponuje działanie przymusowe, musi kierować się zawsze dobrą wiarą i umieć podać motywacje, które usprawiedliwiają to działanie o charakterze przymusowym jako działanie konieczne" (Childress, Faden, Gaare 2002, 173).

Analizując kwestie przymusowego postępowania wobec osób zakażonych i chorych na choroby zakaźne, należy podkreślić, że ochronie prawnej podlega nie tylko życie i zdrowie jednostki, ale również zdrowie publiczne. Do tej wartości odnosi się art. 68, ust. 1 i 4 Konstytucji Rzeczypospolitej Polskiej, zgodnie z którym: „Każdy ma prawo do ochrony zdrowia”, a „Władze publiczne są obowiązane do zwalczania chorób epidemicznych i zapobiegania negatywnym dla zdrowia skutkom degradacji środowiska". Z obowiązkiem państwa dotyczącym ochrony zdrowia i prewencji przed zachorowaniem na choroby zakaźne ,wiąże się obowiązek jednostki polegający na zaakceptowaniu ograniczenia przez władze publiczne podstawowej wolności człowieka, jaką jest prawo do wolności osobistej, o ile celem ograniczenia tej wolności jest zabezpieczenie zdrowia publicznego" (Zajdel-Całkowska 2019, 345). W celu realizacji tych zadań przepisy polskiego prawodawstwa dopuszczają możliwość zastosowania przymusu, by osiągnąć zachowania zmierzające do poddania się świadczeniom zdrowotnym, które z zasady są dobrowolne i zależą od zgody zainteresowanego podmiotu, czyli pacjenta. Zasady postępowania przymusowego zostały określone $\mathrm{w}$ przepisach Ustawy o ochronie zdrowia psychicznego (DzU 2018, poz. 1878), Ustawy o wychowaniu w trzeźwości i przeciwdziałaniu alkoholizmowi (DzU 2016, poz. 487), Ustawy o przeciwdziałaniu 
narkomanii (DzU 2018, poz. 1030) i Ustawy o zapobieganiu oraz zwalczaniu zakażeń i chorób zakaźnych u ludzi (DzU 2018, poz. 151).

$$
* * *
$$

Ukazana $\mathrm{w}$ artykule perspektywa etyczna skoncentrowana na principium odpowiedzialności sytuuje się w połowie drogi pomiędzy wizją libertariańską, która daje pierwszeństwo jednostkom i pozwala na jedynie minimalną interwencję ze strony państwa, a wizją kolektywistyczną, która promuje osiągnięcie największej korzyści wspólnej a prawa indywidualne widzi jako zależne od woli wspólnoty. Zaproponowana w artykule perspektywa etyczna zbudowana na zasadzie odpowiedzialności, wymaga większej i jasno sformułowanej motywacji, szczególnie kiedy to interwencje dotykają ważnych przestrzeni życia osobistego i niejako występują przeciwko tendencjom liberalnym (ograniczając prawa wolnościowe jednostki), ale i przeciwko tendencjom kolektywistycznym (ograniczając niektóre wybory indywidualne, opierając się na demokratycznych procesach decyzyjnych). Z tej racji w przypadku zastosowania pewnych działań z zakresu zdrowia publicznego niezbędne jest ich oficjalne wprowadzenie i rzetelna informacja co do planowanych przedsięwzięć, które mają kluczową rolę w opracowywaniu podręcznika etyki skoncentrowanej na principium odpowiedzialności. O ile planowane instrumenty reprezentują działania nieprzymusowe w celu ważnych ulepszeń na forum sanitarnym, to oficjalne wprowadzenie i rzetelna informacja są najważniejszymi wskazówkami, jakie etyka odpowiedzialności dzieli z liberalizmem. Jednocześnie w sytuacji, kiedy opieranie się jedynie na działaniach dobrowolnych zawodzi, etyka odpowiedzialności ma obowiązek wypracowywania i proponowania pewnych działań alternatywnych i bardziej efektywnych. Przykładem takiej polityki było na przykład stopniowe wprowadzanie kampanii informacyjnej, koncentrującej się na konieczności używania pasów bezpieczeństwa. W wielu krajach najpierw zachęcano poruszających się pojazdami mechanicznymi do używania pasów bezpieczeństwa poprzez szerokie akcje informacyjne. Rezultatem tej kampanii było wprowadzenie prawa nakazującego używanie pasów bezpieczeństwa w trakcie jazdy samochodem.

Ostatecznie jednak jedną z najważniejszych konsekwencji budowania modelu etycznego na zasadzie odpowiedzialności jest ograniczenie roli państwa na korzyść osób trzecich. Istotnie bowiem, jeśli państwo monopolizuje znaczną część funkcji społecznych, to w konsekwencji traci się poczucie odpowiedzialności wśród jednostek i grup społecznych, które delegują tę przysługującą im inicjatywę państwu. To właśnie stało się we wszystkich państwach byłego bloku komunistycznego w XX wieku. W przeciwieństwie do inercji obywatelskiej trzeba uznać rolę osób trzecich, które pojawiają się jako struk- 
tury pośrednie u boku państwa, a które mają bardzo ważną rolę do odegrania w promocji zdrowia publicznego. Byłoby wielkim zaniedbaniem nierozpoznanie ich potencjalnie ogromnej roli.

Tymi strukturami pośrednimi mogą być instytucje medyczne, instytucje wolontaryjne, firmy, samorządy, szkoły, agencje rządowe (jak na przykład te, które zajmują się kontrolą żywności, napojów, wody), agencje farmaceutyczne, właściciele pubów i restauracji. Ostatnie lata pokazały ogromny wzrost znaczenia wszelkiego rodzaju odpowiedzialnych inicjatyw społecznych. Wiele dużych agend, publikując roczne wyniki swojej aktywności, nie skupia się jedynie na rachunkach finansowych, ale i społecznym zaangażowaniu. Ta funkcja przedsiębiorstw zwykła być nazywana społeczną odpowiedzialnością biznesu (corporate social responsibility - CSR). Jest to z pewnością godny zauważenia typ odpowiedzialności, ponieważ rodzi pewne nowe pytania natury etycznej (Wiemeyer 20014, 28-29). To konsumenci odgrywają aktywną rolę w społecznej odpowiedzialności biznesu, a trwała konsumpcja stanowi element zrównoważonego rozwoju (Cur 2014, 168). Co więcej, podkreślając znaczenie tego rodzaju odpowiedzialności, kolejny raz odkrywa się, że warto zatrzymać się w połowie drogi pomiędzy kolektywizmem a libertarianizmem.

W zgodzie z libertarianizmem odrzucamy stan swoistego przerostu opiekuńczości państwa, które zagarnia dla siebie wszystkie działania w zakresie zdrowia publicznego i które niejako przymusza obywateli do tego, aby byli zdrowi. Jednocześnie zgodnie z libertarianizmem uznaje się, że w promocji zdrowia ważną rolę w odpowiedzialnej społeczności ma nie tylko państwo, ale i jednostki oraz rodziny, grupy oraz biznes. $Z$ drugiej strony jednak warto podkreślić, że zwolennicy tendencji wolnościowych, kładący nacisk na podejmowanie wyborów indywidualnych, nie biorą pod uwagę faktu, że podejmowane są one w środowisku, w którym funkcjonują pewne wartości i przyzwyczajenia. Dlatego ludzie bardzo często w pasywny sposób podchodzą do nowej - różnej od będącej w zastosowaniu - polityki środowiskowej. Z tej racji państwo musi w pierwszej kolejności zobowiązać firmy handlowe do poważnego podejścia do społecznej odpowiedzialności biznesu, określając w jasny sposób czynniki zachęty i czynniki zniechęcenia, dając w ten sposób pewną formę nowej praktyce, która może z czasem stać się normą zwyczajową. W drugiej kolejności zaś, jeśli zabrakłoby tej społecznej odpowiedzialności ze strony firmy i w wyniku jej działalności byłoby narażone na niebezpieczeństwo zdrowie ludności, państwo powinno interweniować w sposób bezpośredni. 


\title{
PUBLIC HEALTH - RETHINK BIOETHICS. FROM THE PRINCIPLE OF AUTONOMY TO THE PRINCIPLE OF RESPONSIBILITY
}

\begin{abstract}
There has been a growing tendency lately among bioethics specialists to use a new paradigm of ethical reflection. So far the dominant bioethical principle has been the principle of autonomy of a patient. In the context of care for public health, the principle of responsibility is gradually becoming more important. Undoubtedly this new reflection enriches the fairly short academic history of bioethical research and adds new value to it. This article shows certain elements of medical ethos and research ethics from a medical perspective, which should be analysed as a part of preventive medicine focused on the principle of responsibility. Without such an approach, it would be extremely difficult to take justified measures in the area of public health.
\end{abstract}

Keywords: Bioethics; public health; the principle of responsibility; compulsory measures; voluntary measures

Słowa kluczowe: bioetyka; zdrowie publiczne; zasada odpowiedzialności; środki przymusowe; środki dobrowolne

\section{BIBLIOGRAFIA}

Bayer, Ronald i Amy L. Fairchild. 2004. The genesis of public health ethics. Bioethics 18(6), 473-492 .

Biggs, Herman Michael. 1987. Preventive Medicine in the City of New York. New York: BIGGS.

Bzdęga, Jerzy. 2010. Epidemiologia niektórych chorób zakaźnych. W: Epidemiologia w zdrowiu publicznym, red. Jerzy Bzdęga, Anita Gębska-Kuczerowska, 369-377. Warszawa: PZWL.

Callahan, Daniel i Bruce Jennings. 2002. Ethics and public health: forging a strong relationship. American Journal of Public Health 92(2), 169-176.

Chauvin, Tatiana, Tomasz Stawecki i Piotr Winczorek. 2019 ${ }^{13}$. Wstęp do prawodawstwa. Warszawa: C.H. Beck.

Childress, James, Ruth Faden i Ruth Gaare. 2002. Public health ethics: mapping the terrain. Journal of Law and Medical Ethics, 30(2),170-178.

Cur, Ewelina. 2014. Trwała konsumpcja jako element idei zrównoważonego rozwoju. W: Społeczna odpowiedzialność gospodarski. Perspektywa interdyscyplinarna, red. Stanisław Fel. 159-178. Lublin: Wyd. KUL.

D’Agostino, Francesco i Laura Palazzani. 2007. Bioetica. Nozioni fondamentali. Brescia: La Scuola.

Daniels, Norman. 2000. Accountability for reasonableness. Brtitish Medical Journal, 321, 1300-1301.

Gostin, Lawrence. 2000. Public Health Law: Power, Duty. Berkeley: Restraint.

Guttman, Nuritt i Salmon Charles. 2004. Guilt, fear, stigma and knowledge gaps. Bioethics, 18(6), 531-552. 
Jędrychowski, Wiesław. 2010. Epidemiologia w medycynie klinicznej i zdrowiu publicznym. Podręcznik dla studentów i lekarzy. Kraków: Wyd. UJ.

Kass, Nancy. 2001. An ethics framework for public health. American Journal of Public Health, 91(11), 1776-1786.

Kowalski, Edmund. 2009. Osoba i bioetyka. Zagadnienia biomedyczne dla duszpasterzy i katechetów. Kraków: Homo Dei.

Mepham, Ben. 2008. Bioetyka. Wprowadzenie dla studentów nauk biologicznych. Warszawa: PWN.

Pacian, Anna. 2014. Profilaktyka zakażeń wirusem HIV i uzależnień wśród dzieci i młodzieży. W: Zdrowie publiczne, red. Teresa Kulik i Anna Pacian. 155-176. Warszawa: PZWL.

Papieska Rada ds. Duszpasterstwa Służby Zdrowia. 2017. Nowa Karta Pracowników Stużby Zdrowia. Katowice: KSJ.

Ricoeur, Paul. 1995. Le juste, Paris: Esprit.

Rogers, Wendy i Dan Brock. 2004. Editorial. Bioethics 18(1), 3.

Stuart Mill, John. 1976. On Liberty. Harmondsworth.

Turoldo, Fabrizio. 2011. Bioetica ed etica della responsabilità. Dai fondamenti alle applicazioni pratiche. Assisi: Citadella.

Turoldo, Fabrizio. 2014. Breve storia della bioetica. Torino: Lindau.

Ustawa z dnia 19.08.1994 o ochronie zdrowia psychicznego. 2018. DzU, poz. 1878.

Ustawa z dnia 26.10.1982 o wychowaniu w trzeźwości i przeciwdziałaniu alkoholizmowi. 2016. DzU, poz. 487.

Ustawa z dnia 29.07.2005 o przeciwdziałaniu narkomanii. 2018. DzU, poz. 1030.

Ustawa z dnia 5.12.2008 o zapobieganiu oraz zwalczaniu zakażeń i chorób zakaźnych u ludzi. 2018. DzU, poz. 151.

Wiemeyer, Joachim. 2014. Etyka przedsiębiorstwa w chrześcijańskiej perspektywie społeczno-etycznej. W: Spoleczna odpowiedzialność gospodarski. Perspektywa interdyscyplinarna, red. Stanisław Fel. 17-38. Lublin: KUL.

Wojtczak, Andrzej. 2009. Zdrowie publiczne wyzwaniem dla systemów zdrowia XXI wieku. Warszawa: PZWL.

Wróbel, Józef. 1999. Człowiek i medycyna. Teologicznomoralne podstawy ingerencji medycznych. Kraków: Wyd. Księży Sercanów.

Zajdel-Całkowska, Justyna. 2019. Prawo medyczne. Warszawa: PZWL.

Wojciech Surmiak - ks. dr nauk teologicznych w zakresie teologii moralnej, prodziekan ds. kształcenia i studentów Wydziału Teologicznego Uniwersytetu Śląskiego w Katowicach, członek Europejskiego Stowarzyszenia Teologii Katolickiej - przewodniczący Sekcji Polskiej, członek Stowarzyszenia Teologów Moralistów - członek Zarządu Stowarzyszenia, delegat Konferencji Episkopatu Polski przy Europejskim Forum Duszpasterzy Akademickich, członek Uczelnianej Komisji Bioetycznej ds. Badań Naukowych przy Akademii Wychowania Fizycznego w Katowicach, członek Zespołu ds. Leczenia Zaburzeń Rozwoju Płci przy Górnośląskim Centrum Zdrowia Dziecka im. Jana Pawła II w Katowicach. 